\title{
Exploring producers' motivations and challenges within a farmers' market
}

\author{
Rosario Michel-Villarreal, Eliseo Luis Vilalta-Perdomo and Martin Hingley \\ Lincoln International Business School, University of Lincoln, Lincoln, UK
}

\begin{abstract}
Purpose - To explore food producers' motivations and challenges whilst participating in short food supply chains (SFSCs). This paper compares findings with previous literature and investigates the topic in the context of producers' motivations.

Design/methodology/approach - The paper includes a literature review concerning producers' motivations to engage in SFSCs. A case study was designed to investigate motivations underlying producers' engagement in SFSCs, as well as the challenges that they face. Semi-structured interviews were conducted in a farmers' market located in Mexico. Thematic analysis is used to identify the principal issues for producers'. Propositions based on findings are presented.

Findings - Findings suggest that small, large, part-time and full-time producers are willing to engage with farmers' markets (FMs) for diverse primary economic and non-economic motivations. Individual and collective challenges were also identified.

Originality/value - This research helps to explain producers' motivations and challenges within SFSCs in an under-researched context, namely a focus on producers' and in the Global South.
\end{abstract}

Keywords Short Food Supply Chains, farmers' markets, farmers' economic and non-economic motivations, challenges, Mexico

Paper type Research paper

\section{Introduction}

Case studies about individuals organising themselves and interacting with food systems in an alternative way have been documented since the late 1990s. Initiatives involve both consumers and producers looking for alternatives to conventional food networks, and their varied motives for doing so. Consumers are becoming more aware about environmental, health and animal welfare issues. On the supply side, producers are looking for ways to recapture value within their supply chains, in order to ameliorate the impact of the price squeeze (Renting et al., 2003); with disproportionate value often accruing to larger and powerful retailers (Hingley, 2005). To exemplify alternative approaches, farmers' markets (FMs), community-supported agriculture (CSA), box schemes, cooperatives, farm shops and other initiatives have all been used (MichelVillarreal et al., 2019). The phenomena have been studied from various theoretical and conceptual perspectives such as alternative food networks (AFNs) (Sage, 2003; Watts et al., 2005), short food supply chains (SFSCs) (Renting et al., 2003) and more recently, civic food networks (Bos and Owen, 2016; Renting et al., 2012).

Extensive research has been conducted around consumers' perceptions of SFSCs (Crawford et al., 2018; Dodds and Holmes, 2017), consumers' behaviour towards purchasing in SFSCs (Giampietri et al., 2016), consumers' motivations underlying their preference for SFSCs (Elghannam et al., 2018; Petrescu et al., 2017) and consumers' challenges within SFSCs (Garner and Ayala, 2018). In contrast, the issue of producers' motivations to engage and the challenges that they face remain under researched (Charatsari et al., 2018). Only recently, some 
studies have attempted to shed some light on this (Bellante, 2017; Cox et al., 2008; Demartini et al., 2017). Even though recent efforts have started explaining producers' motivations to participate in SFSCs, the collective challenges that they encounter within SFSCs have received little attention. Furthermore, the most recent literature is based on evidence from developed countries in the Global North (Dados and Connell, 2012) where SFSCs are widespread. The same issues are yet to be addressed in the low- and middle-income countries in the Global South (Bellante, 2017). Hence, there are opportunities for further research in the areas highlighted previously. In order to address these shortcomings in existing literature, we pose the following two research questions:

$R Q 1$. What are the producers' motivations to engage with SFSCs?

$R Q 2$. What challenges do producers face within SFSCs?

As such, the main aim of this research will be to understand producers' motivations to engage with SFSCs and challenges that they face. Particularly, we are interested in the motivations and challenges of producers in the Global South, due to the geographical imbalance in current literature indicated above. To do so, in this paper we adopt the theoretical perspective that uses the concept of SFSCs as the framework for analysis and discussion.

The remainder of this paper consists of five main sections. Section 2 presents a review of the current state of literature with a focus on overarching concepts such as SFSCs and farmers' markets (FMs). We also review literature that addresses the motivations to engage with SFSCs and challenges within SFSCs from a producer's perspective. The selected research approach is justified and explained in section 3; and a case study approach is considered the most appropriate. Section 4 summarises the results from the analysis of collected data. In section 5, we present a discussion of emerging findings in relation to existing literature and formulate some propositions. Lastly, the paper concludes with a summary of implications, limitations and recommendations for future research in section 6.

\section{Literature review}

This literature review contains three main sections. First, we review the different understandings of SFSCs; secondly, we focus on the concept of FMs as an instance of the SFSC phenomena, and finally, discussion addresses producers' reasons and motivations to engage with SFSCs according to the extant literature.

\subsection{Short food supply chains, SFSCs}

SFSCs have been conceptualised through a variety of criteria such as number of intermediaries, physical distance, social relations and organisational structure. For instance, the French Ministry of Agriculture, Food and Forestry relies on just one criterion and suggests that short food supply chains are those systems that involve only one or fewer intermediaries (Galli and Brunori, 2013). Building on this, the European Network for Rural Development defines SFSCs in relation to the reduction of intermediaries, and physical distance between the producers and consumers being at a minimum (Peters, 2012). Conversely, Marsden et al. (2000) propose that the number of intermediaries or the physical distance that products travel is not what ultimately distinguishes SFSCs; instead, the connection between consumers and producers through products embedded with information is what is critical. Following a similar line of thought, Renting et al., (2003) define SFSCs in terms of 'shortened' producer-consumer relations and information-embedded products. They propose a framework to better understand the wide empirical variety of SFSCs using two interrelated dimensions, organisational structures and quality definitions/conventions. The first dimension relates to organisational structures and to the "specific mechanisms entailed in these to extend relations in time and space" (Renting et 
al., 2003, 399). Here, they propose three different categories: face-to-face SFSCs, proximate SFSCs and extended SFSCs, with each category involving a different degree of proximity between producers and consumers. The second dimension relates to the quality dimensions or conventions "communicated to consumers to convince them of paying premium prices" within SFSCs. They identify two main categories of quality definitions. The first one is defined by the regional or artisanal characteristics of products (i.e. speciality, fair trade, etc.) whereas the second one relates to the ecological or natural characteristics (i.e. organic, free range, etc.).

Topics such as the role of trust in consumer-producer relationships (Giampietri et al, 2018), social relations during shopping (Kopczyńska, 2017) and consumer-producer interactions and collaboration (Opitz et al., 2017) have been widely investigated. Despite the growing body of literature, the issue of producers' motivations to engage in SFSCs continues to be under-explored (Charatsari et al., 2018). To date, researchers' preference for studying social relations within SFSCs hinders the opportunity to better understand what motivates producers to create or participate in these supply chain arrangements in the first place. We argue that refocusing attention on the drivers to engage in SFSCs may provide further understanding regarding producers' expectations, the types of relations that they build inside SFSCs and practical approaches to nurturing SFSC structures. This may support policymakers in developing better informed decisions on how to strengthen producers' sustainability through their predisposition to participate in and even collaborate within SFSCs.

\subsection{Farmers' Markets as a real-life manifestation of SFSCs: Challenges and motivations to engage}

Whilst aware of the variety of SFSCs configurations, FMs have been chosen in this paper as instances of the broader SFSCs phenomena. In terms of research, due to their inherent arrangement (direct selling), FMs represent an instance of SFSCs where the boundaries in the roles played by producers and consumers are well-defined. This facilitates collecting observations of roles, preferences, intentions and motivations of producers in particular; the latter being the focus of this research. Furthermore, FMs have experienced recent rapid growth and diffusion (Murphy, 2011) and are one of the most widespread and popular forms of SFSCs (Arabska, 2018), hence they provide a useful ground to study the phenomena in possibly under researched contexts. In this regard, a bibliometric study by Figueroa-Rodríguez et al., (2019) identified that the most frequently cited publications related to FMs mainly document cases in North America and Western Europe. Additionally, and unlike other SFSCs, FMs have been extensively promoted and funded by local and regional governments (Carey et al., 2011; Savoie-Roskos et al., 2017). Thus, a study focused on FMs could have greater impact in terms of public policymaking.

FMs have been defined as "public areas where fruit and vegetable producers gather to sell their produce directly to consumers" (Figueroa-Rodríguez et al., 2019); although, it has been observed that larger FMs also offer non-agricultural products such as handicrafts (Spilková and Perlín, 2013). Figueroa-Rodríguez et al., (2019) identified some attributes of FMs such as type of products offered, size (i.e. number of stands), hours and days of operation, location, type of property (public vs. private) and origin of products (e.g. local or non-local). Thus, FMs can display a wide variety of configurations depending on their attributes. For instance, just the number of vendors can vary from 20 to 100 (Spilková and Perlín, 2013).

FMs provide positive spillover by bringing producers and consumers together in a particular site at specific times or days, such as market days (Hinrichs, 2000). One of these benefits is creating a platform where actors can interact and exchange information. Brown (2002) identified other potential benefits of FMs, such as an increase in employment and establishment of businesses, improved farm profitability, bigger customer spending, higher diversification of regional agriculture and increased communication and trust between 
producers and consumers. In comparison with other forms of direct selling, such as farm shops, e-commerce, box schemes, FMs seem to provide benefits for a larger number of producers as they involve certain degree of collaboration. However, it has been suggested that, because of their 'alternativeness' in comparison to conventional food systems, FMs tend to attract rather small, local and organic producers (Murphy, 2011; Szmigin et al., 2003). Therefore, their potential impacts could be restricted to certain groups.

In terms of FMs long-term sustainability, it is important to recognise current challenges. Whilst it is true that the number of FMs worldwide keeps growing, they have also been criticised for appealing to a particular demographic and excluding certain social groups (Colasanti et al., 2010; Garner and Ayala, 2018). In particular, several authors suggest that consumers who shop at FMs are women (Onianwa et al., 2006; Stanco et al., 20.19; Ylitalo et al., 2019), who are highly educated (Wolf et al., 2005; Aguirre Gonzaléz, 2009; Spilková, 2018) and have a high income (Onianwa et al., 2006; Baker et al., 2009). However, other studies suggest that evidence to support such claims is inconclusive and therefore propose that FMs' consumer base may be diversifying (Wolf et al., 2005; Byker et al., 2012). Another challenge for FMs is long-term survival. A high failure rate for FMs that are between one and four years old has been documented. This failure rate is also dependent on other factors such as small size, lack of vendors and high manager turnover (Stephenson et al., 2008).

On the supply side, FMs face a variety of problems. For instance, some challenges that limit growth of FMs can be lack of reliable supply and therefore convenient access for the consumer (Garner and Ayala, 2018). Furthermore, producers tend to struggle with getting access to consumers and building networks, because of the significant distance that separates them and the time that they need to invest (Koutsou and Sergaki, 2019). On the demand side, inconvenient location and opening hours have been found to limit consumers' engagement in FMs (Byker et al., 2012). Further, Webber and Dollahite (2008) recognized price as another important barrier to FMs shopping.

Only recently, studies have started to focus on analysing producers' motivations to engage in FMs and other SFSCs. Findings suggest that producers with good communication and collaboration competencies show increased willingness to participate in SFSCs (Charatsari et al., 2018). Furthermore, both economic and non-economic motives may be displayed by producers within SFSCs (Bellante, 2017; Leiper and Clarke-Sather, 2017). Particularly, "diversifying income streams", "educating consumers" and "contributing to local economy" were identified as motivations to engage in a Community Supported Agriculture (CSA) scheme (Cox et al., 2008). A similar study conducted in a farmers' market (FM) identified both economic and social motivations to engage. Producers mentioned economic motivations such as access to higher prices, cutting out intermediaries and close proximity to the FM. Social motivations included meeting community members and direct interaction with consumers. Some of these reasons were also acknowledged as benefits of engaging in a FM in a study conducted in Mexico (Bellante, 2017). All producers interviewed agreed that price premiums are a key reason for their engagement with the FM. A further study conducted in New Zealand found out that the main reason for producers to join FMs was "product promotion" whilst only one vendor considered income from the market as their main income (Guthrie et al., 2006).

Producers also show a marked interest in increasing their sales through SFSCs (Demartini et al., 2017; Migliore et al., 2015). On the other hand, the desire to establish social connections, with consumers and other producers, and protecting the environment are also recognised by some producers (Migliore et al., 2015). Kupke and Page (2015) suggest that producers' attitudes towards engaging in FMs reflect their personal circumstances. They further propose that larger and part-time producers are less motivated to engage in FMs. Brown's (2002) findings support the proposition that larger producers tend to see the economics of FMs as adverse. On the other hand, her findings contradict Kupke and Page's (2015) proposition 
regarding part-time producers' participation in FMs. Her findings suggest that many FMs' producers are part-time producers with additional occupations and household incomes (Brown, 2002).

Overall, these studies provide an overview of producers' motivations to engage with FMs and SFSCs. Although it must be noted that must studies have been conducted in the Global North. Additionally, individual and collective challenges faced by producers already involved in FMs have not been extensively addressed. Investigating such challenges may shed some light on how to improve producers' predisposition to participate in FMs and how to scale-up SFSC initiatives. Accordingly, the main focus of this paper is to expand this body of literature. In particular, we are interested in investigating producers' motivations to engage in FMs and the challenges they may face in the context of emergent economies located in the Global South.

\section{Research design}

The present study seeks to understand a real-life contemporary phenomenon, in depth and within its context. The main focus is on producers' motivations to engage in SFSCs and their challenges. Accordingly, this research relies on the use of case study research (Stake, 1994; Yin, 2014). This method has been chosen because it facilitates a more comprehensive study of social networks and the actions, decisions and motives that they involve (Feagin et al., 1991). Case study is considered useful when the researcher is trying to understand why a decision or a set of decisions were taken (Schramm, 1971), thus it seems particularly suited to investigate why producers decide to engage with SFSCs.

\subsection{Case selection}

This study focuses on the in-depth exploration of a single case. Single cases are selected based on theoretical reasons and not following random or stratified sampling principles (Eisenhardt and Graebner, 2007). The case selected represents an opportunity to explore the phenomena in an under-researched context, the Global South. Thus, it may facilitate contrary replication based on the comparison of emergent findings and existing theory (Eisenhardt, 1989; Yin, 2014). In line with Stake's (1994) view, our approach is an instrumental case study. Therefore, the focus is not on understanding the selected case, but on understanding something in particular, specifically the motivations and challenges of producers within the selected case.

The selected case is a FM located in Mazatlán, a city in the northwest of Mexico. FMs are still nascent phenomena in the Global South (Bellante, 2017). In the case of Mexico, the Mexican Network of Tianguis and Organic Markets (La Red Mexicana de Tianguis y Mercados Orgánicos) had records in 2015 of only 37 FMs, distributed throughout the country (Schwentesius-Rindermann and Gómez-Cruz, 2015).

\subsection{Data collection and analysis}

We used a combination of methods (Yin, 2014), including secondary data from social media and semi-structured interviews for the collection of primary data.

Semi-structured interviews were chosen for data collection as they facilitate the collection of rich data related to participants' views (Saunders et al., 2016). Furthermore, the nature of semi-structured interviews, as opposed to unstructured interviews, may increase reliability by ensuring that the data collection procedures can be replicated (Yin, 2014). Through fourteen questions, the semi-structured interview schedule investigated demographics, product diversification, sales channels, motivation to engage in FMs and challenges faced within the FM. Data was obtained from six producers. Interviews lasted between 15 and 22 minutes. They were audio recorded and later transcribed for analysis. The data was collected during December 2018.

The selection of interviewees was based on two main criteria. Firstly, we excluded non 
farmers, such as craftsmen, as we were particularly interested in investigating motivations and challenges of farmers (urban and rural). Secondly, we used data saturation to determine when to stop interviewing. When using the data saturation approach "decisions about when further data collection is unnecessary are commonly based on the researcher's sense of what they are hearing within interviews" (Saunders et al., 2018, p.1899); this decision is usually made before data analysis. This approach allowed us to acquire a sense of conceptual depth and, therefore, to stop when no additional insights were being gained.

Secondary data was collected from the FM social media, (specifically their Facebook webpage). This particular type of secondary data has proved useful in previous SFSC studies (Bos and Owen, 2016; Hayden and Buck, 2012). Collected secondary data helped to better understand the history of the FMs, the type of vendors involved and the marketing strategies used. To date, the FM does not have a website and their only online communication and advertising channel is their Facebook webpage.

The data analysis process of semi-structured interviews was based on a six-phase thematic analysis approach (Braun and Clarke, 2006). Thematic analysis allowed the coding and categorizing of data, which are processes suited for the systematic, comprehensive and cumulative analysis of case study data (Simons, 2009). The use of tables complements the case study narrative and is essential to emphasise the depth and detail of the empirical evidence (Eisenhardt and Graebner, 2007) and to provide a consistent mapping that readers can follow. From a theory building perspective, the final product of the analysis is a set of propositions that aim to explain the phenomena under study (Eisenhardt, 1989).

\subsection{Research quality and rigour}

Several criteria were used for ensuring the goodness or quality of the research (Lincoln and Guba, 1985). In order to address dependability, two researchers carried out all the phases of the thematic analysis separately. Then, final codes and themes were agreed between the participant researchers. Credibility was addressed by having researchers' interpretations validated by the participants. To this end, transcripts of interviews were sent back to participants for review before proceeding to the thematic analysis. In theory building, internal validity can be addressed by comparing emerging findings with existing literature. In our study, our own findings were contrasted with literature that conflicts with it and literature that presents similar findings. Adopting this strategy can result in increased internal validity and generalizability (Eisenhardt, 1989).

\section{Empirical results}

\subsection{The case study: Mercado Orgánico de Mazatlán (Mazatlan Organic Farmers' Market)}

The SFSC examined in this study is situated near the old town of Mazatlán. Mazatlán is located in a predominantly farming state (Sinaloa) in Mexico. The Mercado Orgánico de Mazatlán (MOM) takes place in a public park every Saturday from $8.00 \mathrm{am}$ to $12.00 \mathrm{pm}$ from November to April. Vendors are commonly producers from nearby rural villages, although some stalls sell food from restaurants and small businesses located in the urban area. According to MOM's Facebook page, their aim is to offer healthy and organic food directly to the final customer without the use of intermediaries.

MOM takes seriously the concept of 'organic', as shown by interviewees who indicated that all of their production must be organic to become part of MOM. They are also required to pay a not specified fee and bring their own tables. From the beginning, they are required to provide a list of the products that they will be selling weekly and they must adhere to it. On the day of our visit at MOM, there were 18 stalls selling a wide variety of organic fruits, vegetables, meats, cheeses, eggs, herbs, flowers, etc. Processed food such as artisanal salsas, jams, coffee, ice cream, pastries, bread, and traditional products such as tamales and handmade tortillas are 
also sold in the market. Additionally, there were a few stalls selling handicrafts.

\subsection{Profile of producers within MOM}

The first section of the semi-structured interview consisted of several questions aimed at better understanding producers' characteristics. Table 1 summarizes key demographics.

Table 1. Characteristics of MOM producers interviewed (Own elaboration).

\begin{tabular}{|c|c|c|c|c|}
\hline Interviewee & Gender & Occupation & $\begin{array}{l}\text { Agricultural } \\
\text { system }\end{array}$ & Produce \\
\hline I1 & Male & $\begin{array}{l}\text { Agronomist/ } \\
\text { part-time } \\
\text { producer }\end{array}$ & $\begin{array}{l}\text { Organic and } \\
\text { urban agriculture }\end{array}$ & $\begin{array}{l}\text { More than } 40 \text { different seasonal } \\
\text { fruits, vegetables, herbs and } \\
\text { plants. Some processed } \\
\text { products, such as salsas and } \\
\text { jams }\end{array}$ \\
\hline $\mathbf{I 2}$ & Female & $\begin{array}{l}\text { Full-time } \\
\text { producer }\end{array}$ & $\begin{array}{l}\text { Organic } \\
\text { agriculture and } \\
\text { hydroponics }\end{array}$ & $\begin{array}{l}\text { Several types of lettuces, } \\
\text { spinach, beans and others } \\
\text { seasonal produce }\end{array}$ \\
\hline I3 & Male & $\begin{array}{l}\text { Agronomist/ } \\
\text { part-time } \\
\text { producer }\end{array}$ & $\begin{array}{l}\text { Organic } \\
\text { agriculture }\end{array}$ & $\begin{array}{l}\text { Strelitzia reginae flower (aka } \\
\text { bird of paradise flower), small } \\
\text { bananas, avocado and starfruit } \\
\text { when in season }\end{array}$ \\
\hline I4 & Female & $\begin{array}{l}\text { Full-time } \\
\text { producer }\end{array}$ & $\begin{array}{l}\text { Organic } \\
\text { agriculture }\end{array}$ & Organic chicken and eggs \\
\hline I5 & Male & $\begin{array}{l}\text { Full-time } \\
\text { producer }\end{array}$ & $\begin{array}{l}\text { Conventional and } \\
\text { organic } \\
\text { agriculture }\end{array}$ & $\begin{array}{l}\text { More than } 70 \text { products. Only } \\
\text { sells a few seasonal organic } \\
\text { products in the FM }\end{array}$ \\
\hline I6 & Female & $\begin{array}{l}\text { Full-time } \\
\text { producer }\end{array}$ & $\begin{array}{l}\text { Organic } \\
\text { agriculture }\end{array}$ & $\begin{array}{l}\text { A wide variety of seasonal fruits } \\
\text { and vegetables, plus herbs and } \\
\text { handmade traditional products, } \\
\text { such as tortillas and tamales }\end{array}$ \\
\hline
\end{tabular}

\subsection{Producers' motivations to engage in the MOM}

Findings from interviews suggest that there are a number of economic and non-economic motivations to engage in MOM. All interviewees agreed that access to better prices is one of the main benefits of participating in MOM, which they complemented with a wide variety of other economic motivations. MOM is seen as a mechanism that generates opportunities for brand positioning, advertising, creation of jobs, access to better prices and niche markets (see table 2).

Table 2. Motivations to engage in the Mercado Orgánico de Mazatlán. (Own elaboration).

\begin{tabular}{lcll}
\hline $\begin{array}{l}\text { Emergent } \\
\text { themes }\end{array}$ & Codes & Illustrative quotes \\
\hline $\begin{array}{l}\text { Economic } \\
\text { motivations }\end{array}$ & $\bullet$ & Access to better prices & "The bird of paradise flower, our main \\
& $\bullet$ & Access to a niche market & $\begin{array}{l}\text { product, can be sold to a higher price } \\
\text { in the MOM than in local flower } \\
\text { shops" }\end{array}$ \\
& $\bullet$ & $\begin{array}{l}\text { Brand positioning strategy and } \\
\text { building credibility }\end{array}$ \\
& - & Direct selling & \\
\hline
\end{tabular}


- Needs to produce and sell organic because she lives in a protected nature reserve

- Network connections to additional buyers (i.e. restaurants)

"Attending an organic FMs is a way for them to increase credibility and trust in their organic products." "The main reason to attend the MOM is to promote our own brand of organic and hydroponic lettuces. we are also interested in connecting with new potential buyers in the city of Mazatlán. Whilst I attend the stall in the MOM, my husband visits restaurants and hotels to offer our products"

- Promoting own brand

Non-economic motivations
- It represents an opportunity to reconnect with nature (going back to the land)

- Desire to offer healthier products
"The MOM gave me the chance to combine my full-time job and my passion for farming"

"We are interested in providing a healthier alternative to consumers"

Even though all interviewees recognise the economic advantages of engaging with the FM, two of them cited non-economic reasons as their main motivation to join in the first place. Interviewee 1 explained that his motivations have to do with a desire to reconnect with nature. Through the interview, it was noticeable that he is a strong supporter of organic agriculture and its many benefits for the environment, producers' livelihoods and human health. This suggests that his ethical motivations outweigh his economic motivations. Non-economic motivations were also closely linked to the producers' operational constraints.

"Since the area where our farm is located was declared a nature reserve by the federal government in 2000 , we have not been allowed to use conventional agriculture anymore or clear any land to increase production" (Interviewee 6, 2018).

Thus, she joined MOM because it represented a source of employment and livelihood for her. She is now able to use organic agriculture and get fair prices for her produce.

\subsection{Producers' challenges within MOM}

A wide variety of challenges were identified by producers. We divide them into individual challenges and collective challenges (see summary in table 3). Individual challenges relate to struggles specific to each producer, in terms of transport, production, operations, etc.; whereas collective challenges have to do with difficulties that they all face as a group inside MOM.

Table 3. Challenges to engage in the Mercado Orgánico de Mazatlán (MOM). (Own elaboration).

\begin{tabular}{|c|c|c|}
\hline Emergent themes & Codes & Illustrative quotes \\
\hline $\begin{array}{l}\text { Individual } \\
\text { challenges }\end{array}$ & $\begin{array}{l}\text { Increased labour requirements for } \\
\text { organic products. } \\
\text { - Lack of Mexican organic } \\
\text { certification schemes. } \\
\text { - Storage requirements for organic } \\
\text { eggs. } \\
\text { - Transportation of fragile products. } \\
\text { - Travelling expenses to get to the } \\
\text { MOM. } \\
\text { - Weather-related events affecting } \\
\text { organic production. }\end{array}$ & $\begin{array}{l}\text { "This year, I was hesitant to join } \\
\text { the MOM because I did not have } \\
\text { any fresh produce. I sowed } \\
\text { multiple times this year and } \\
\text { nothing grew because the heat } \\
\text { has been too intense. A few } \\
\text { plants are starting to grow only } \\
\text { now" } \\
\text { "I cannot produce more because } \\
\text { organic production is very time } \\
\text { and labour demanding" }\end{array}$ \\
\hline
\end{tabular}




\begin{tabular}{lll} 
& & $\begin{array}{l}\text { "One of the main challenges for } \\
\text { us has been the handling and } \\
\text { transportation of the flowers as } \\
\text { they are very fragile and lose } \\
\text { value easily" }\end{array}$ \\
\hline $\begin{array}{l}\text { Collective } \\
\text { challenges }\end{array}$ & $\begin{array}{l}\text { Attracting more customers to the } \\
\text { MOM. }\end{array}$ & $\begin{array}{l}\text { "I have been attending the } \\
\text { MOM for a few years now and I } \\
\text { still have the same customers } \\
\text { buying every week" } \\
\text { among members of the MOM. }\end{array}$ \\
$\begin{array}{l}\text { Lack of public awareness about } \\
\text { the benefits of local/organic } \\
\text { products. }\end{array}$ & $\begin{array}{l}\text { "One of the main difficulties we } \\
\text { face is that people do not know } \\
\text { or appreciate the organic } \\
\text { produce" }\end{array}$ \\
\hline
\end{tabular}

Several interviewees views coincided concerning the same individual challenges. For instance, transport and lack of certification schemes were recurrent themes. On the other hand, the discussion about collective challenges showed more contradictions. For instance, some interviewees agreed that attracting more customers to MOM was a key challenge, but others did not agree. Some were even positive about this aspect explaining that as time passes more customers are attending MOM.

\section{Discussion}

In this paper, we have paid attention to the personal stories of producers and aimed at understanding how those stories can further explain the SFSCs phenomenon. In their study on rural producers in South Australia, Kupke and Page (2015) suggest that the attitudes of producers towards engaging in FMs relate to personal circumstances: level of farm income, being full or part time producer, family commitments and farm size. Our findings suggest that motivations go beyond those personal circumstances and are closely linked to personal stories of each producer. Economic motivations such as networking opportunities, brand positioning and access to a niche market, as well as non-economic motivations such as the opportunity to reconnect with nature and adopting and promoting healthier diets, can also be seen as primary motivations to engage in FMs. This is in line with previous research which has shown that producers may show both economic and social reasons to engage in FMs and other SFSCs (Cox et al., 2008; Leiper and Clarke-Sather, 2017; Vilalta-Perdomo and Hingley, 2018).

However, conversely to Kupke and Page (2015) findings, who suggest that larger producers and part-time time producers are less likely to engage in FMs, our findings at MOM suggest that both larger producers and part-time producers are also willing to engage in FMs, for varied economic and non-economic reasons, mainly explained through their personal life experiences. For instance, larger producers may be interested in brand positioning, marketing, networking opportunities and alternative distribution channels outside of industrialised supply chains; which may or not reflect in better prices but may also be explained as risk management strategies.

Access to higher prices has been recognised as one of the economic benefits and motivation to engage in SFSCs (Bellante, 2017; Demartini et al., 2017). Leiper and ClarkeSather (2017) conducted a study in FMs in the USA and suggested that most producers rely on their FM sales as a substantial source of income and as key to their economic survival strategy. However, our findings showed that the main income of most producers does not always come from the sales in FMs. With the exception of one producer, most of them have off-farm jobs or use a variety of sale channels. Furthermore, our findings indicate that economic reasons were not always the main trigger for producers to join MOM. Our findings also support Brown's (2002) proposition which suggests that some producers are primarily motivated to use FMs 
because they feel that it is the best and/or only option to sell their products.

In summary, our findings contradict the Migliore et al. (2015) suggestion that the majority of producers engaged in SFSCs are social entrepreneurs with social-oriented behaviour and weak self-interest. MOM producers interviewed can be characterised as independent-minded entrepreneurs, who largely seek profit improvement, business growth or brand positioning. Even though they recognise the environmental benefits of organic food, there is no evidence to confirm this to be their main motivation to engage with MOM. More specifically, most producers displayed self-interest and little desire of establishing social or community connections through the FMs. The previous discussion leads us to our first two propositions:

P1. Small, large, part-time and full-time producers may be willing to engage with FMs for diverse primary economic and non-economic motivations such as networking opportunities, brand positioning, access to niche markets, the opportunity to reconnect with nature and the desire to adopt and promote healthier diets.

$P 2$. Producers within FMs can be independent-minded entrepreneurs, who primarily seek profit improvement, business growth or brand positioning, with little desire of establishing social or community connections with other producers or consumers.

Significant time and labour required for organic production, crop loss due to weather-related conditions and a limited consumer base, were identified through our research as important challenges. All of these challenges were also identified by Bellante (2017), who investigated producers' challenges in another FM in Mexico. Producers also identified challenges related to stock handling expenses. This suggests that engagement with a SFSCs may represent additional costs that producers would not need to incur if they used conventional sale channels. However, the recognised access to higher prices through FMs may compensate for the increased handling expenses. Whether or not premium prices can absorb the increased marketing and handling costs is still unclear (Demartini et al, 2017; Hardesty and Leff, 2010). Lastly, this challenge also suggests that producers engaged in some forms of SFSC, such as FMs, may need to undertake activities usually associated with other actors in a conventional food supply chain, such as a distributor, manufacturer or retailer. This not only implies increased costs but also the need to develop new skills. These findings extend the discussion related to the limited potential of SFSCs in terms of their impact on regional economies. The exclusionary orientation, rather than openness, of SFSCs have been highlighted (Tregear, 2011). The case study analysed in this paper is exclusionary by definition; only organic producers can join and get access to the benefits of the FM. Furthermore, only those producers who have access to transport and can cover extra handling expenses will be able to engage with MOM. Finally, producers will need to adopt additional roles in order to join and perform in the FM. This last discussion leads us to a final proposition:

P3. FMs may empower producers to develop and grow their farms, brands and businesses. Nonetheless, this may imply a need to adopt additional roles and undertake activities usually associated to other actors in a conventional food supply chain, such as distributor, manufacturer or retailer. This may signify increased costs but also a requirement to develop new skills.

Collective challenges such as attracting more customers to the FM, lack of public awareness about the benefits of organic products and communication and collaboration among producers, were also identified from the interviews. Interestingly, the current level of communication and 
collaboration was seen as good by some producers, but for others this aspect is still challenging. In particular, Interviewee 3 suggested that product-exchange or bartering, could be implemented in order to reduce surplus produce at the end of the day. This practice was identified as an economic benefit in another FM in Mexico (Bellante, 2017). Overall, past research on SFSCs has focused on investigating the interaction between consumers and producers, and the relationships among producers continue to be under researched. Thus, further comparison of our own findings regarding collective challenges proved difficult.

\section{Implications for practice and future research}

Experiences of FMs, such as the ones presented in this paper, offer important insights regarding the difficulties of transitioning or integrating into SFSCs. In a country with a long history of small-scale agriculture (Bellante, 2017), SFSCs can be an alternative for producers who lack the resources to incorporate into conventional industrialised food networks. Equally, findings presented here can be useful for scaling-up the incipient "SFSCs movement" in Mexico, and other developing countries. By understanding current motivations and challenges, we may be able to better inform stakeholders and support the design of effective public policies. SFSCs have become an important aspect of agricultural policies in the Global North but they haven't been fully adopted by governments in the Global South. Therefore, we support FAO's (2017) recommendation to consider SFSCs as a strategic line of action within the three levels (federal, state and municipal) of government in Mexico to strengthen small-scale agriculture. At the same time, we acknowledge that future research is needed to better understand the policies needed to successfully embed these initiatives in developing economies.

This paper indicates the need for additional studies concerning practices and motivations to engage in FMs. Current literature focuses on countries of the Global North and suggests that producers that engage in FMs mainly operate under a predominantly economic-based rationales. This paper shows that there are other reasons for producers in the Global South to participate in FMs. Furthermore, this paper suggests that FMs impact in society may go beyond direct economic effects. Interviewees at Mercado Orgánico de Mazatlán showed that FMs are beneficial for increasing the quality and quantity of secure employment in a traditionally unstable economic sector. Thus, FMs have the potential of creating not only better incomes but also secure access to markets and opportunities for value addition, which is key for the achievement of the Sustainable Development Goal 2 (United Nations, 2020).

\section{Conclusion}

The main aim of this research has been to understand producers' motivations to engage with FMs and the challenges they face. We chose to conduct a case study to collect in-depth data from a FM in Mexico. We were particularly interested in understanding motivations and challenges of producers in the Global South, as there seems to be a geographical imbalance in current literature. Thus, this study revealed main motivations to participate in an organic FM in Mexico and the challenges faced by members. Even though 'access to better prices' was recognised as a benefit of joining a FM, it was not identified as the main motivation to join in the first place. On the contrary, other economic motivations such as networking opportunities, brand positioning and access to a niche market were recognised as main triggers. Furthermore, non-economic motivations such as the opportunity to reconnect with nature and adopting and promoting healthier diets, were also described as primary motivations to engage in FMs. Understating of social and environmental benefits of SFSCs was displayed by most producers. However, they were not cited as the main motivations to join the FM either. Overall, most producers displayed self-interest and little desire of establishing long-term social or community connections through the FM. Ultimately, we suggested that individual motivations and challenges are largely explained by personal life experiences of producers. Thus, findings from 
this study are not easily transferable. However, we provide theoretical propositions that can be tested in other contexts to corroborate findings. This would improve current understanding of the benefits and challenges of SFSCs in developing countries.

Despite the multiple motivations and individual challenges of producers in our case study, evidences suggest that FMs can be vehicles for the creation of full- or part-time employment and therefore wider economic development. This is particularly relevant where socio-economic circumstances are not favourable for small-farmers. Furthermore, FMs can empower producers to develop and grow their farms, brands and businesses. Nonetheless, this may imply the need to take on additional roles (i.e. distributor, retailer, entrepreneur). In this sense, from a policymaking point of view, this study agrees with recent arguments around the need to support producers in the development of additional skills and capabilities (Charatsari et al., 2018; Debruyne et al., 2016). We identify this as an area for future research as there is limited understanding of the skills or support needed by producers to successfully integrate their commercial activities into a FMs or other type of short food supply chain.

Through comparison with existing literature, we noticed similarities and differences in terms of motivations and challenges across FMs and other forms of SFSCs. Motivations and challenges may be influenced not only by the national or local socio-economic context of SFSCs and producers, but also by the type, such as FM, CSA, cooperatives, etc., and by attributes of the SFSCs under study. SFSCs are so diverse and heterogeneous, that even proximate FMs located in similar contexts can display different circumstances and characteristics that may explain motivations and challenges of producers (Garner and Ayala, 2018). The choice of a single case study was justified by the need to acquire an in-depth understating of producers' motivations and challenges. However, we recognise the need for further research to test, expand and refine our propositions using additional cases to develop more rigorous theory.

\section{References}

Aguirre González, J. (2009), "Market trends and consumer profile at the organic farmers market in Costa Rica", British Food Journal, Vol. 111 No. 5, pp. 498-510, doi: 10.1108/00070700910957320

Arabska, E. (2018), "Farmers' markets as a business model encouraging sustainable production and consumption", Visegrad Journal on Bioeconomy and Sustainable Development, Vol. 7, No. 1, pp. 2-6.

Baker, D., Hamshaw, K. and Kolodinsky, J. (2009), "Who shops at the market? Using consumer surveys to grow farmers' markets: findings from a regional market in northwestern Vermont", Journal of Extension, Vol. 47 No. 6, pp. 1-9.

Bellante, L. (2017) "Building the local food movement in Chiapas, Mexico: rationales, benefits, and limitations", Agriculture and Human Values, Vol. 34 Issue 1, pp. 119-135, doi: 10.1007/s10460-016-9700-9.

Bos, E. and Owen, L. (2016), "Virtual reconnection: The online spaces of alternative food networks in England", Journal of Rural Studies, Vol. 45, pp. 1-14, doi: 10.1016/j.jrurstud.2016.02.016

Braun, V. and Clarke, V. (2006), "Using thematic analysis in psychology", Qualitative Research in Psychology, Vol. 3, No. 2, pp. 77-101. 
Brown, A. (2002), "Farmers' market research 1940-2000: an inventory and review", American Journal of Alternative Agriculture, Vol. 17 No. 4, pp. 167-176.

Byker, C., Shanks, J., Misyak, S. and Serrano, E. (2012), "Characterizing farmers' market shoppers: A literature review", Journal of Hunger and Environmental Nutrition, Vol. 7 No.1, pp. 38-52, doi: 10.1080/19320248.2012.650074.

Carey, L., Bell, P., Duff, A., Sheridan, M. and Shields, M. (2011), "Farmers' Market consumers: a Scottish perspective", International Journal of Consumer Studies, Vol. 35, pp. 300-306.

Charatsari, C., Kitsios, F., Stafyla, A., Aidonis, D. and Lioutas, E. (2018), "Antecedents of farmers' willingness to participate in short food supply chains", British Food Journal, Vol. 120, No. 10, pp. 2317-2333.

Colasanti, K., Conner, D. and Smalley, S. (2010), 'Understanding barriers to farmers' market patronage in Michigan: perspectives from marginalized populations", Journal of Hunger and Environmental Nutrition, Vol. 5 No. 3, pp. 316-338, doi: 10.1080/19320248.2010.504097.

Cox, R., Holloway, L., Venn, L., Dowler, L., Hein, J. R., Kneafsey, M. and Tuomainen, H. (2008), "Common ground? Motivations for participation in a community-supported agriculture scheme”, Local Environment, Vol. 13 No. 3, pp. 203-218, doi: 10.1080/13549830701669153.

Crawford, B., Byun, R., Mitchell, E., Thompson, S., Jalaludin, B. and Siranda Torvaldsen (2018), "Seeking fresh food and supporting local producers: perceptions and motivations of farmers' market customers", Australian Planner, Vol. 55 No. 1, pp. 28-35, doi: 10.1080/07293682.2018.1499668.

Dados, N. and Connell, R. (2012), “The Global South”, Contexts, Vol. 11 No. 1, pp. 12-13., doi: $10.1177 / 1536504212436479$.

Debruyne, L. Triste, L. and Marchand, F. (2016), "Key competencies for an agroecological farmer", paper presented at the $5^{\text {th }}$ Belgian Agroecology Meeting, 20 September, Gent, available

at: https://pure.ilvo.be/portal/files/4642052/Debruyne_BAM_2016_Key_competencies_for_an_a groecological_farmer.pdf (accessed 15 March 2019).

Demartini, E., Gaviglio, A. and Pirani, A. (2017), "Farmers' motivation and perceived effects of participating in short food supply chains: evidence from a North Italian survey", Agricultural Economics, Vol. 63 Issue 5, pp. 204-217, doi: 10.17221/323/2015-AGRICECON.

Dodds, R. and Holmes, M.R. (2017), “Local Versus Visitor Perceptions of Farmers' Markets", Journal of Food Products Marketing, Vol. 23 No. 2, pp. 167-185, doi: 10.1080/10454446.2017.1244785.

Eisenhardt, K.M. (1989), "Building Theories from Case Study Research", The Academy of Management Review, Vol. 14 Issue 4, pp. 532-550, doi: 10.2307/258557.

Eisenhardt, K.M. and Graebner, M.E. (2007), “Theory building from cases: Opportunities and challenges", Academy of Management Journal, Vol. 50 Issue 1, pp. 25-32. 
Elghannam, A., Arroyo, J., Eldesouky, A. and Mesias, F.J. (2018), "A cross-cultural consumers' perspective on social media-based short food supply chains", British Food Journal, Vol. 120 No. 10, pp. 2210-2221.

FAO (2016), "Fapda Country Fact Sheet On Food And Agriculture Policy Trends", Available at: http://www.fao.org/3/a-i6006e.pdf (Accessed 18 September 2018).

FAO (2017), "Guía para el desarrollo de mercados de productores", available at: http://www.fao.org/3/a-i8096s.pdf (accessed 20 December 2019).

Feagin, J., Orum, A., and Sjoberg, G. (1991) A case for case study. Chapel Hill, NC: University of North Carolina Press.

Figueroa-Rodríguez, K.A., Álvarez-Ávila, M.C., Hernández Castillo, F., Schwentesius Rindermann, R. and Figueroa-Sandoval, B. (2019), "Farmers' Market Actors, Dynamics, and Attributes: A Bibliometric Study", Sustainability Vol. 11 Issue 3, pp. 745, doi: 10.3390/su11030745.

Galli. F., and Brunori, G. (eds.) (2013), "Short Food Supply Chains as drivers of sustainable development", Evidence Document developed in the framework of the FP7 project FOODLINKS (GA No. 265287), Laboratorio di studi rurali Sismondi, ISBN 978-88-90896-01-9

Garner, B. and Ayala, C. (2018), "Consumer supply-chain demands and challenges at farmers' markets", British Food Journal, Vol. 120 Issue: 12, pp. 2734-2747, doi: 10.1108/BFJ-03-20180154.

Giampietri, E., Finco, A. and Del Giudice, T. (2016), "Exploring consumers' behaviour towards short food supply chains", British Food Journal, Vol. 118 Issue 3, pp. 618-631.

Giampietri, E., Verneau, F., Del Giudice, T., Carfora, V. and Finco, A. (2018), “A Theory of Planned behaviour perspective for investigating the role of trust in consumer purchasing decision related to short food supply chains", Food Quality and Preference, Vol. 64, pp.160-166.

Guthrie, J., Guthrie, A., Lawson, R., \& Cameron, A. (2006), "Farmers' markets: the small business counter-revolution in food production and retailing", British Food Journal, Vol. 108 No. 7, pp. 560-573, doi: 10.1108/00070700610676370.

Hardesty, S. D. and Leff, P. (2010), "Determining marketing costs and returns in alternative marketing channels", Renewable Agriculture and Food Systems, Vol. 25, pp. 24-34.

Hayden, J. and Buck, D. (2012), "Doing community supported agriculture: Tactile space, affect and effects of membership", Geoforum, Vol. 43 Issue 2, pp. 332-342, doi: 10.1016/j.geoforum.2011.08.003.

Hingley, M. K. (2005), "Power imbalanced relationships: cases from UK fresh food supply", International Journal of Retail and Distribution Management, Vol. 33, No. 8, pp. 551-564.

Hinrichs, C.C. (2000) "Embeddedness and local food systems: notes on two types of direct agricultural market”, Journal of Rural Studies, Vol. 16, pp. 295-303. 
Kopczyńska, E. (2017), "Economies of Acquaintances: Social Relations during Shopping at Food Markets and in Consumers' Food Cooperatives", East European Politics and Societies, Vol. 31, No. 3, pp. 637-658.

Koutsou, S. and Sergaki, P. (2019), "Producers' cooperative products in short food supply chains: consumers' response", British Food Journal, Vol. 122 No. 1, pp. 198-211, doi: $10.1177 / 0973258615597407$

Kupke, V. and Page, G. (2015), "Does the farmer want a market? Factors impacting on participation by local producers in farmers markets", Pacific Rim Property Research Journal, Vol. 21 Issue 1, pp. 61-75, doi: 10.1080/14445921.2015.1026199.

Leiper, C. and Clarke-Sather, A. (2017), "Co-creating an alternative: the moral economy of participating in farmers' markets", Local Environment, Vol. 22 Issue 7, pp. 840-858, doi: 10.1080/13549839.2017.1296822.

Lincoln, Y. S., and Guba, E. G. (1985), Naturalistic Inquiry. Newbury Park, CA: Sage Publications.

Marsden, T., Banks, J. and Bristow, G. (2000), "Food Supply Chain Approaches: Exploring their Role in Rural Development", Sociologia Ruralis, Vol. 40, No. 4, pp. 424438.

Michel-Villarreal, R.; Hingley, M.; Canavari, M.; Bregoli, I. (2019), "Sustainability in Alternative Food Networks: A Systematic Literature Review", Sustainability, Vol. 11, pp. 859, doi: 10.3390/su11030859.

Migliore, G., Schifani, G., Romeo, P., Hashem, S. and Cembalo, L. (2015), “Are Farmers in Alternative Food Networks Social Entrepreneurs? Evidence from a Behavioral Approach", Journal of Agricultural \& Environmental Ethics, Vol. 28 Issue 5, pp. 885-903, doi: 10.1007/s10806-015-9562-y.

Murphy, A. (2011), "Farmers' markets as retail spaces", International Journal of Retail \& Distribution Management, Vol. 39 No. 8, pp. 582-597.

Onianwa, O., Mojica, M. and Wheelock, G. (2006), "Consumer characteristics and views regarding farmers markets: an examination of on-site survey data of Alabama consumers", Journal of Food Distribution Research, Vol. 37, pp. 121-124.

Opitz, I., Specht, K., Piorr, A., Siebert, R. and Zasada, I. (2017), "Effects of consumerproducer interactions in alternative food networks on consumers' learning about food and agriculture", Moravian Geographical Reports, Vol. 25 No. 3, pp. 181-191.

Peters, R. (ed.)(2012), Local Food and Short Supply Chains, EU Rural Review №12.

Petrescu, D.C., Petrescu-Mag, R.M., Burny, P. and Azadi, H. (2017), "A new wave in Romania: organic food. Consumers' motivations, perceptions, and habits", Agroecology and Sustainable Food Systems, Vol. 41 Issue 1, pp. 46-75, doi: 10.1080/21683565.2016.1243602.

Renting, H., Marsden, T. and Banks, J. (2003), "Understanding alternative food networks: exploring the role of short food supply chains in rural development", Environment and Planning A, Vol. 35, pp. 393-411.

Renting, H., Schermer, M. and Rossi, A. (2012), "Building Food Democracy: Exploring Civic Food Networks and Newly Emerging Forms of Food Citizenship", International Journal of Sociology of Agriculture \& Food, Vol. 19, pp. 289-307. 
Sage, C. (2003) "Social embeddedness and relations of regard: Altenrative 'good food' networks in south-west Ireland", Journal of Rural Studies, Vol. 19, pp. 47-60.

Saunders, B., Sim, J., Kingstone, T., Baker, S., Waterfield, J. and Bartlam, B. (2017), "Saturation in qualitative research: exploring its conceptualization and operationalization", Qual Quant, Vol. 52 Issue 4, pp. 1893-907, doi: 10.1007/s11135-017-0574-8.

Saunders, M., Lewis, P. and Thornhill, A. (2016), Research Methods for Business Students, Pearson, England.

Savoie-Roskos, M.R., Wengreen, H., Gast, J., LeBlanc, H. and Durward, C. (2017), "Understanding the Experiences of Low-Income Individuals Receiving Farmers' Market Incentives in the United States: A Qualitative Study", Health Promotion Practice, Vol. 18, No. 6, pp. 869-878, doi: 10.1177/1524839917715438.

Schramm, W. (1971), "Notes on case studies for instructional media projects", Working paper for Academy of Educational Development, Washington D.C.

Schwentesius-Rindermann, R. and Gómez-Cruz, M.A. (2015), "La Red Mexicana de Tianguis y Mercados Orgánicos - Renovando sistemas de abasto de bienes de primera necesidad para pequeños productores y muchos consumidores", Revista Ciencias de la Salud, Vol. 24 No. 4, pp. 100-114.

Simons, H. (2009), Case Study Research: In-Depth Understanding in Context. London: Sage.

Spilková, J. (2018), “Tell Me Where You Shop, and I Will Tell You Who You Are”: Czech Shopper Profiles According to Traditional, Large-Scale and Alternative Retail Options, Moravian Geographical Reports, Vol. 26 No. 3, pp. 186-198, doi: 10.2478/mgr2018-0015.

Spilková, J. and Perlín, R. (2013), "Farmers' markets in Czechia: Risks and possibilities", Journal of Rural Studies, Vol. 32, pp. 220-229.

Stake, R.E. (1994), The art of case study research. Thousand Oaks, CA: Sage

Stanco, M., Lerro, M., Marotta, G. and Nazzaro, C. (2019), “Consumers' and farmers' characteristics in short food supply chains: an exploratory analysis", Studies in Agricultural Economics, Vol. 121, pp. 67-74, doi: 10.7896/j.1905.

Stephenson, G., Lev, L. and Brewer, L. (2008), “'I'm getting desperate': what we know about farmers' markets that fail", Renewable Agriculture and Food Systems, Vol. 23 No. 3, pp. 188-199.

Szmigin, I., Maddock, S. and Carrigan, M. (2003), "Conceptualising community consumption: farmers' markets and the older consumer”, British Food Journal, Vol. 105 No. 8, pp. 542-50, doi: 10.1080/19320248.2010.504097.

Tregear, A. (2011), "Progressing knowledge in alternative and local food networks: Critical reflections and a research agenda", Journal of Rural Studies, Vol. 27 Issue 4, pp. 419-430.

United Nations (2020), “Goal 2: Zero Hunger”, available at:

https://www.un.org/sustainabledevelopment/hunger/ (accessed 3 January 2020). 
Vilalta-Perdomo, E. \& Hingley, M. (2018) 'Beyond Links and Chains in Food Supply: A community OR perspective'. Journal of the Operational Research Society, 69(4), pp. 580588, doi:10.1057/s41274-017-0252-1.

Watts, D.C.H., Ilbery, B. and Maye, D. (2005), "Making reconnections in agro-food geography: Alternative systems of food provision", Progress in Human Geography, Vol. 29 , pp. 22-40.

Webber, C. and Dollahite, J. (2008), “Attitudes and behaviors of low-income food heads of households toward sustainable food systems concepts", Journal of Hunger and Environmental Nutrition, Vol. 3, pp. 186-205.

Wolf, M., Spittler, A. and Ahern, J. (2005), “A profile of farmers' market consumers and the perceived advantages of produce sold at farmers' markets", Journal of Food Distribution Research, Vol. 36, pp. 192-201.

Yin, R. K. (2009). Case study research: Design and methods (4th Ed.), Thousand Oaks, CA: Sage.

Ylitaloa, K.R., Duringa, C., Thomasa, K., Ezellb, K., Lillardb, P. and Scott, J. (2019), “The Veggie Van: Customer characteristics, fruit and vegetable consumption, and barriers to healthy eating among shoppers at a mobile farmers market in the United States", Appetite, Vol. 133, pp. 279-285, doi: 10.1016/j.appet.2018.11.025. 